\title{
Culturable bacteria from an Alpine coniferous forest site: biodegradation potential of organic polymers and pollutants
}

\author{
Tanja Berger $^{1} \cdot$ Caroline Poyntner $^{1} \cdot$ Rosa Margesin $^{1}$ (I) \\ Received: 3 April 2020 / Accepted: 16 September 2020 / Published online: 25 September 2020 \\ (C) The Author(s) 2020
}

\begin{abstract}
The potential of the culturable bacterial community from an Alpine coniferous forest site for the degradation of organic polymers and pollutants at low $\left(5{ }^{\circ} \mathrm{C}\right)$ and moderate $\left(20^{\circ} \mathrm{C}\right)$ temperatures was evaluated. The majority of the 68 strains belonged to the phylum Proteobacteria (77\%). Other strains were related to Bacteroidetes (12\%), Alphaproteobacteria (4\%), Actinobacteria (3\%), and Firmicutes (3\%). The strains were grouped into 42 different OTUs. The highest bacterial diversity was found within the phylum Bacteroidetes. All strains, except one, could grow at temperatures from 5 to $25^{\circ} \mathrm{C}$. The production of enzyme activities involved in the degradation of organic polymers present in plant litter (carboxymethyl cellulose, microgranular cellulose, xylan, polygalacturonic acid) was almost comparable at $5{ }^{\circ} \mathrm{C}(68 \%)$ and $20^{\circ} \mathrm{C}(63 \%)$. Utilizers of lignin compounds (lignosulfonic acid, lignin alkali) as sole carbon source were found to a higher extent at $20^{\circ} \mathrm{C}(57 \%)$ than at $5{ }^{\circ} \mathrm{C}(24 \%)$, but the relative fractions among positively tested strains utilizing these compounds were almost identical at the two temperatures. Similar results were noted for utilizers of organic pollutants (n-hexadecane, diesel oil, phenol, glyphosate) as sole carbon source. More than two-thirds showed constitutively expressed catechol-1,2-dioxygenase activity both at $5{ }^{\circ} \mathrm{C}(74 \%)$ and $20^{\circ} \mathrm{C}(66 \%)$. Complete phenol $(2.5$ $\mathrm{mmol} / \mathrm{L}$ ) degradation by strain Paraburkholderia aromaticivorans AR20-38 was demonstrated at $0-30{ }^{\circ} \mathrm{C}$, amounts up to 7.5 $\mathrm{mmol} / \mathrm{L}$ phenol were fully degraded at $10-30^{\circ} \mathrm{C}$. These results are useful to better understand the effect of changing temperatures on microorganisms involved in litter degradation and nutrient turnover in Alpine forest soils.
\end{abstract}

\section{Introduction}

Climate change is increasing surface temperatures worldwide and is one of the largest challenges facing our planet. Besides a number of physical and chemical alterations, such as increasing soil temperatures, carbon dioxide levels, or nitrogen deposition, climate change will affect the structure, diversity, and abundance of soil microbial communities. Knowledge on the response of soil microorganisms to environmental changes is essential to understand and predict ecosystem processes $(\mathrm{Li}$ et al. 2014). Alpine mountain systems are especially vulnerable. The European Alps already experienced an increase in the

Electronic supplementary material The online version of this article (https://doi.org/10.1007/s12223-020-00825-1) contains supplementary material, which is available to authorized users.

Rosa Margesin

rosa.margesin@uibk.ac.at

1 Institute of Microbiology, University of Innsbruck, Technikerstrasse 25, 6020 Innsbruck, Austria annual minimum temperature of ca. $2{ }^{\circ} \mathrm{C}$ during the twentieth century (Gobiet et al. 2014).

The largest pool of carbon on Earth is stored in forest soils. Since forests are known to act as carbon sinks (Baldrian 2017), they play an important role in global carbon cycling and consequently affect climate. The main carbon reservoir in forests is soil organic matter (SOM). Soil microorganisms play a crucial role in the transformation and decomposition of SOM (Žifčáková et al. 2017). In earlier studies, we examined the effects of altitude and season on the microbial diversity and activity along an Alpine elevation gradient (França et al. 2016; Siles et al. 2016). The functional characterization of the soil microbial communities demonstrated that soil microorganisms at the coniferous forest site $(1724-1737 \mathrm{~m}$ above sea level) have a higher resistance to environmental changes (contents of SOM and nutrients, soil temperature, soil $\mathrm{pH}$ ) than those from a deciduous forest site at lower altitude (Siles and Margesin 2017). At this site, genes related to cellulose (mainly genes encoding cellobiase and exoglucanase) and lignin (phenol oxidase) degradation and genes involved in bioremediation, such as for the degradation of aromatic compounds, herbicides, and pesticides, were found. The 
coniferous forest site was also characterized by significantly increased levels of genes involved in the degradation of both labile (starch) and recalcitrant (cellulose, pectin, and lignin) carbon compounds in autumn compared with spring (Siles and Margesin 2017).

It is recognized that a combination of culture-dependent and culture-independent methods is successful in exploring the abundance and diversity of microorganisms in environmental samples. However, culture-dependent methods are still required to understand microbial functions, physiology, adaptation mechanisms, and community dynamics in their environment and to be able to detect and use microorganisms and their associated bioproducts for biotechnological applications (Gebbie et al. 2020). Low-temperature environments present a large resource for the discovery of useful microorganisms with a wide range of potential biotechnological applications (Collins and Margesin 2019).

To gain further insights into the bacterial activity at the above-mentioned and well-studied coniferous forest site R, we evaluated the biodegradation potential of the culturable bacterial community isolated earlier in autumn (França et al. 2016). We characterized 68 strains with regard to the production of enzymes involved in the degradation of organic compounds and with regard to the utilization of lignins and organic pollutants as sole carbon source. To reveal the phenotypes adapted to the site-specific conditions, bacterial activities were evaluated at low $\left(5^{\circ} \mathrm{C}\right)$ and moderate $\left(20^{\circ} \mathrm{C}\right)$ temperatures.

\section{Materials and methods}

\section{Sampling and isolation of bacteria}

The sampling site (coniferous Alpine forest) has been described in detail by França et al. (2016). Briefly, the site R (N 46 35' 16.2", E $11^{\circ} 26^{\prime} 4.9^{\prime \prime}$ ) is located $7 \mathrm{~km}$ north of Bozen/Bolzano below the Rittner Horn at an altitude of 1724-1737 m above sea level. The pedogenic substratum consists of rhyolite (quartz-porphyry) and the soil was classified as haplic podzol (FAO). The site consists of coniferous forest close to the timber line, dominated by Picea abies, P. cembra, Larix decidua, and Vaccinium myrtillus. The climate is subalpine-continental with an annual precipitation of $1000 \mathrm{~mm}$, a mean annual air temperature of $4.0^{\circ} \mathrm{C}$, a mean annual soil temperature of $4.3{ }^{\circ} \mathrm{C}$, a minimum annual soil temperature of $1.9^{\circ} \mathrm{C}$, and a maximum annual soil temperature of $6.1{ }^{\circ} \mathrm{C}$ (França et al. 2016).

Soil samples were collected from this site in late autumn (15 October 2014). Immediately after sampling, soil samples were transported in cooled boxes to the laboratory, sieved $(<2$ $\mathrm{mm}$ ), and immediately analyzed for culturable microorganisms. The determination of soil characteristics demonstrated an acidic soil $\mathrm{pH}$ (3.4). Contents of humus, TOC (total organic carbon), and total $\mathrm{N}$ were $53 \%, 40 \%$, and $1.4 \%$, respectively. The $\mathrm{C} / \mathrm{N}$ ratio was 23 (França et al. 2016). The 68 bacterial strains described in this study were isolated on R2A agar supplemented with cycloheximide $(400 \mu \mathrm{g} / \mathrm{mL})$ at $20^{\circ} \mathrm{C}$ (França et al. 2016) and stored at $-80^{\circ} \mathrm{C}$ in R2A broth supplemented with $15 \%$ (w/v) glycerol.

\section{Identification and phylogenetic analysis of culturable bacteria}

Bacterial genomic DNAs were extracted by microwave lysis (Sánchez-Hidalgo et al. 2012). The primers 27F (5'-AGAG TTTGATCCTGGCTC-3') and 1541R (5'-AAGG AGGTGATCCAGCCGCA-3') (Lane 1991) were used for partial $16 \mathrm{~S}$ rRNA gene amplification. Each $50 \mu \mathrm{L}$ PCR reaction contained $5 \mu \mathrm{L}$ PCR buffer (10x) (BIORON GmbH, Germany), $1 \mu \mathrm{L} \mathrm{MgCl}_{2}$ (100 mmol/L) (BIORON GmbH), 1 $\mu \mathrm{L}$ dNTPs $(10 \mathrm{mmol} / \mathrm{L}$ each) (Sigma, USA), $2 \mu \mathrm{L}$ each forward and reverse primers $(10 \mu \mathrm{mol} / \mathrm{L})$ (Eurofins Genomics, Germany), $0.5 \mu \mathrm{L}$ Taq polymerase $(5 \mathrm{U} / \mu \mathrm{L})$ (BIORON $\mathrm{GmbH}), 4 \mu \mathrm{L}$ DNA solution, and $34.5 \mu \mathrm{L} \mathrm{H}_{2} \mathrm{O}$. The thermal cycling program was as follows: (i) 5 min at $95{ }^{\circ} \mathrm{C}$; (ii) 35 cycles of $30 \mathrm{~s}$ at $95^{\circ} \mathrm{C}, 30 \mathrm{~s}$ at $52^{\circ} \mathrm{C}$, and $1 \mathrm{~min}$ at $72{ }^{\circ} \mathrm{C}$; and (iii) a final elongation step of $10 \mathrm{~min}$ at $72^{\circ} \mathrm{C} .16 \mathrm{~S}$ rRNA PCR gene products were visualized on an ethidium bromidestained agarose gel, purified using GENEJET PCR purification kit (Thermo Fisher Scientific Inc., USA) according to the manufacturer's instructions and Sanger sequenced (Microsynth AG, Switzerland).

The sequences were manually edited using the software MEGA ver. $X$ and the nearest phylogenetic neighbors were determined for each strain using the EzTazon-e Database (Kim et al. 2012). This information was used to describe the taxonomic bacterial diversity. The sequences were then clustered into operational taxonomic units (OTUs) at $99 \%$ identity using average neighbor algorithm with the software Mothur v.1.39.3 (Schloss et al. 2009). All 16S rRNA gene sequences were deposited in GenBank NCBI under the accession numbers shown in Fig. 1 and Table S1.

Phylogenetic trees of the $6816 \mathrm{~S}$ sequences (Fig. 1) and 42 reference strains resulting from the OTU clustering (Fig. S1) were constructed to visualize their relationships using Mega X (Kumar et al. 2018). Maximum composite likelihood approach was used and after testing for the best model, the

Fig. 1 Bootstrap consensus tree with the highest log likelihood (7828.05) using maximum likelihood method and the general time reversible model is shown. Numbers next to the branches show percentage of trees in which the associated taxa clustered and different classes and phyla are marked on the right. The species resulting from EzTazon-e Database, OTUs, and Genbank Accession numbers are given next to the species number. The tree is drawn to scale, with branch lengths measured in the number of substitutions per site 


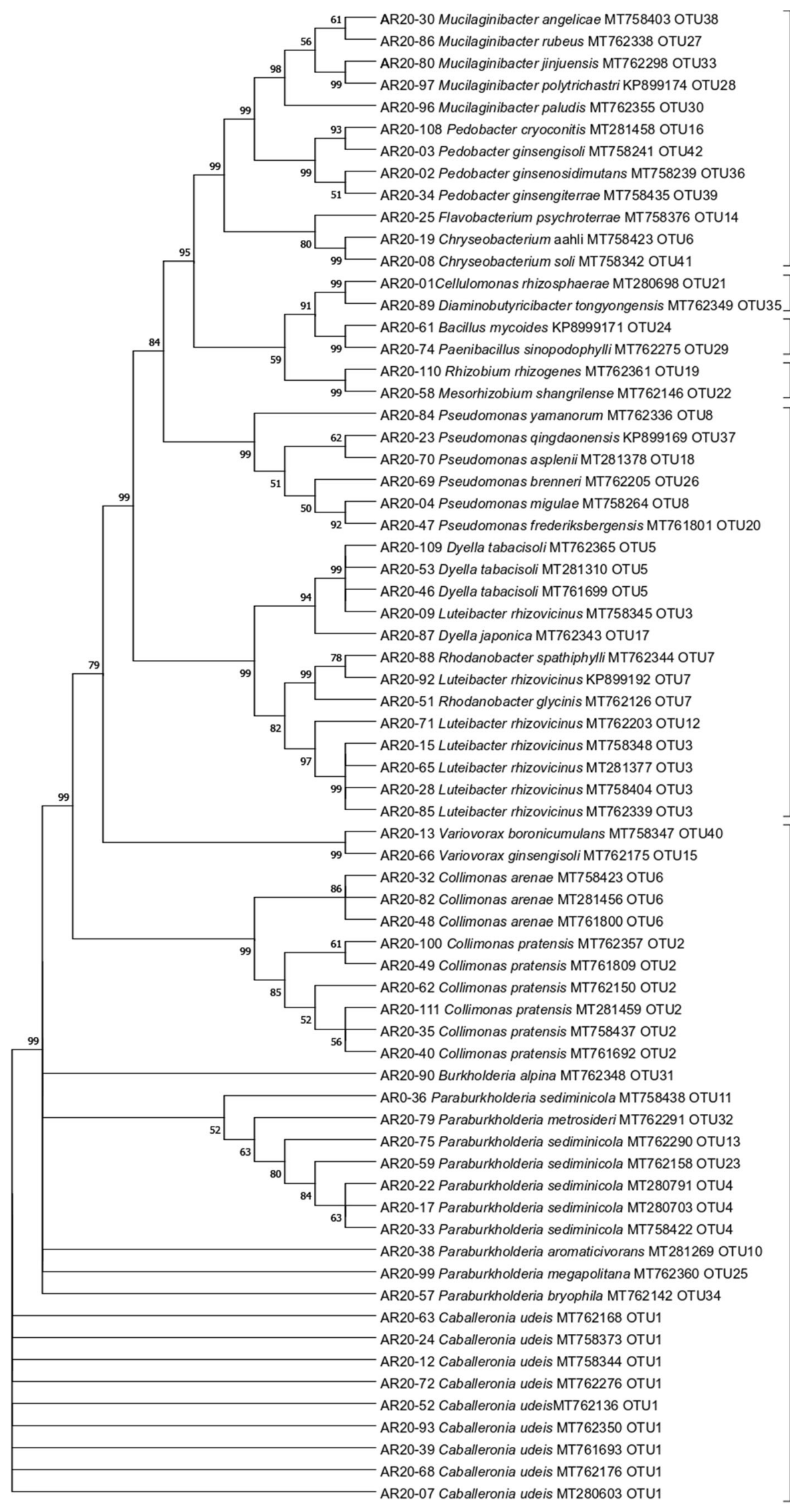

BACTEROIDETES

ACTINOBACTERIA

FIRMICUTES

ALPHAPROTEOBACTERIA

GAMMAPROTEOBACTERIA 
general time reversible model (Nei and Kumar 2000) was chosen for Fig. 1 and the Kimura 2-parameter model (Kimura 1980) was chosen for Fig. S1. A discrete gamma distribution $(5$ categories $(+\mathrm{G}$, parameter $=0.4770$ Fig. 1 / 0.5792 Fig. S1)) was used and some sites were evolutionary invariable $([+\mathrm{I}], 26.40 \%$ sites Fig. $1 / 26.94 \%$ sites Fig. S1). The partial deletion option was chosen, and bootstrapping values were calculated using the neighbor joining method (resampling size $n=2000$ ).

\section{Growth temperature range of bacterial strains}

Suspensions of bacterial cells (pre-grown on R2A) in $0.9 \%$ $\mathrm{NaCl}$ were used to inoculate $\mathrm{R} 2 \mathrm{~A}$ agar plates that were incubated at $0,5,10,15,20,25,30$, and $35^{\circ} \mathrm{C}$, using two replicates per strain and temperatures. Growth was monitored over an incubation time of 21 days.

\section{Screening for enzyme activities}

Activities of cellulases, xylanase, and pectate lyase of the 68 strains were evaluated on R2A agar plates supplemented with carboxymethyl cellulose (CMC, Sigma C-5678), microgranular cellulose (micCell, Sigma C-6413), xylan (from larchwood, Sigma X-3875), and polygalacturonic acid (PGA, from orange, Sigma P-7276), using two replicates per strain and compound. For each compound, a concentration of $5 \mathrm{~g} / \mathrm{L}(0.5 \%$ $\mathrm{w} / \mathrm{v})$ was used. Inoculated plates without these compounds were used as negative controls. After incubation at $5{ }^{\circ} \mathrm{C}$ (14 days) and $20{ }^{\circ} \mathrm{C}$ ( 7 days), plates containing celluloses and xylan were flooded with Congo red solution $(1 \mathrm{mg} / \mathrm{mL})$ for $15 \mathrm{~min}$ followed by flooding with $1 \mathrm{~mol} / \mathrm{L} \mathrm{NaCl}$ for $15 \mathrm{~min}$ and rinsing with $1 \mathrm{~mol} / \mathrm{L}$ $\mathrm{NaCl}$ (Li et al. 2016). A positive reaction was noted when transparent zones around the colonies were detected. PGA-containing plates were flooded with $1 \mathrm{~mol} / \mathrm{L}$ calcium chloride for $20 \mathrm{~min}$; a positive reaction was noted when distinct cloudy halos appeared around enzyme-producing colonies (Margesin et al. 2005).

For the evaluation of constitutively expressed catechol dioxygenase activities, the 68 bacterial strains were grown at $5{ }^{\circ} \mathrm{C}$ and at $20^{\circ} \mathrm{C}$ on R2A agar plates. Cells were collected from the agar plate and suspended in $0.9 \% \mathrm{NaCl}$; the $\mathrm{A}_{600}$ value of all cell suspensions was adjusted to 1.5 with $0.9 \%$ $\mathrm{NaCl}$ (= standardized cell suspensions). By using these standardized cell suspensions, it was possible to compare the activities of the strains. Catechol-1,2-dioxygenase (C1,2D) and catechol-2,3-dioxygenase (C2,3D) were quantified spectrophotometrically as described (Nakazawa and Nakazawa 1970; Nozaki 1970; Margesin et al. 2013). The product formation of cis,cis-muconic acid from catechol $(260 \mathrm{~nm})$ indicated $\mathrm{C} 1,2 \mathrm{D}$, while the formation of 2-hydroxymuconic semialdehyde $(375 \mathrm{~nm})$ was indicative of C2,3D. Three replicates were used per strain and enzyme.

\section{Screening for utilization of lignin as sole carbon source}

Suspensions of bacterial cells in $0.9 \% \mathrm{NaCl}$ were used to inoculate plates composed of mineral medium (Margesin and Schinner 1997) with purified agar, without yeast extract. The medium contained either lignin sulfonic acid (LSS) (Roth 8999, water soluble, $2 \mathrm{~g} / \mathrm{L}$ ) or lignin alkali (Aldrich 370959, insoluble in water, $5 \mathrm{~g} / \mathrm{L}$ ) the sole carbon source. Inoculated plates without these compounds were used as negative controls. Plates were incubated up to 21 days at $5{ }^{\circ} \mathrm{C}$ and at $20^{\circ} \mathrm{C}$, using two replicates per strain and compound, and growth was monitored regularly.

The LSS-utilizing strains AR20-38 and AR20-07 were further tested in liquid culture in 100-mL Erlenmeyer flasks containing $20 \mathrm{~mL}$ of mineral medium to determine the effect of temperature $\left(0-30{ }^{\circ} \mathrm{C}\right)$ and LSS concentration $(2,4,6,8,10$, $15 \mathrm{~g} / \mathrm{L})$ on growth. Growth $\left(\mathrm{A}_{600}\right)$ was monitored regularly.

\section{Screening for utilization of organic pollutants as sole carbon source}

Suspensions of bacterial cells in $0.9 \% \mathrm{NaCl}$ were used to inoculate mineral medium (see above) agar plates containing purified agar. The plates were amended with one of the following compounds as the sole carbon source: $n$-hexadecane ( $50 \mu \mathrm{L}$ per plate, supplemented via the vapor phase), diesel oil ( $40 \mu \mathrm{L}$ per plate, supplemented via the vapor phase), phenol $(2.5 \mathrm{mmol} / \mathrm{L}=235 \mathrm{mg} / \mathrm{L})$, and glyphosate (Roundup $\odot 1 \mathrm{~g} / \mathrm{L}$ ). Inoculated plates without these compounds were used as negative controls. Plates were incubated up to $14-21$ days at $5{ }^{\circ} \mathrm{C}$ and at $20^{\circ} \mathrm{C}$, using two replicates per strain and compound, and growth was monitored regularly.

The phenol-utilizing strain AR20-38 was further tested in liquid culture in $100-\mathrm{mL}$ Erlenmeyer flasks containing $20 \mathrm{~mL}$ of mineral medium to determine the effect of temperature $\left(0-35{ }^{\circ} \mathrm{C}\right)$ and phenol concentration $(2.5,5,7.5,10 \mathrm{mmol} / \mathrm{L})$ on phenol degradation. Growth $\left(\mathrm{A}_{600}\right)$ and the residual phenol content (Allsop et al. 1993; Margesin et al. 2013) were monitored regularly. Phenol concentration was determined in culture supernatants that were filtered $(0.2 \mu \mathrm{m}$, Minsart RC4 17821) after centrifugation. High-performance liquid chromatography (HPLC) was carried out by using a RP-18 column (5 $\mu \mathrm{m} \times 100 \mathrm{~mm}$, Lichrospher, Merck), detection at $220 \mathrm{~nm}$ (Shimadzu SPD-20A), and an eluent flow of $0.5 \mathrm{~mL} / \mathrm{min}$. The elution time for phenol was approx. $7.5 \mathrm{~min}$. The phenol calibration curve was prepared in mineral medium. 


\section{Results}

\section{Culturable bacterial diversity}

The phylogenetic relationship between the studied strains is shown in Fig. 1. The majority of the studied 68 strains (52 strains, $77 \%$ ) belonged to the phylum Proteobacteria, with a predominance of the two classes Betaproteobacteria $(60 \%$ of Proteobacteria) and Gammaproteobacteria (37\% of Proteobacteria), while Alphaproteobacteria were present in a very low amount (4\%) (Fig. 1, Table 1). All representatives of Betaproteobacteria belonged to the order Burkholderiales, with a predominance of the genera Paraburkholderia and Caballeronia; Xanthomonadales dominated among Gammaproteobacteria. Only 18\% (12 strains) were represented by Bacteroidetes. The remaining 4 strains were related to the phyla Actinobacteria and Firmicutes (2 strains each) (Fig. 1, Table 1). Thus, the fraction of Gram-positive bacteria (6\%) was very low compared with the fraction of Gram-negative bacteria (94\%).

The 68 strains were grouped into 42 different OTUs at $99 \%$ identity. The OTUs 1 and 2, classified at order level as Burkholderiales (Betaproteobacteria) and clustering 9 and 6 strains, respectively, were the most abundant ones. Twentysix OTUs were classified as Proteobacteria, 12 as Bacteroidetes, 2 as Firmicutes, and the remaining 2 as Actinobacteria. The phylogenetic tree (Fig. S1) of the 42 reference strains obtained from the OTU analysis shows that strains from the same phylum are clustering together. The highest bacterial diversity was found within the phylum Bacteroidetes since the 12 isolates belonging to this group were grouped into 12 different OTUs (Fig. 1).

\section{Growth temperature range}

All 68 tested strains could grow at temperatures ranging from 10 to $25{ }^{\circ} \mathrm{C}$; only one strain was unable to grow at $5{ }^{\circ} \mathrm{C}$ (Table S1). About two-thirds (44 strains, 65\%) showed growth at $0{ }^{\circ} \mathrm{C}$. Neither all four representatives of Grampositive bacteria nor all three representatives of OTU 4 (Betaproteobacteria, Paraburkholderia sp.) could grow at 0 ${ }^{\circ} \mathrm{C}$. In contrast, all 9 representatives of OTU 1 (Betaproteobacteria, Caballeronia sp.) and OTU 2 (Betaproteobacteria, Collimonas ssp.) showed generally good growth at temperatures below $20{ }^{\circ} \mathrm{C}$. Fifty-seven strains $(84 \%)$ were able to grow at $30^{\circ} \mathrm{C}$; the 3 representatives of OTU 7 (Gammaproteobacteria) could not grow at this temperature. Only 2 strains showed growth at $35^{\circ} \mathrm{C}$, however, not at $40^{\circ} \mathrm{C}$. One of these two strains (Pseudomonas sp. AR20-23) showed growth over the whole temperature range of $0-35^{\circ} \mathrm{C}$, while the other strain (Bacillus sp. AR20-61) was the only one among the 68 strains unable to grow at $5{ }^{\circ} \mathrm{C}$.
Table 1 Identification of the studied 68 culturable bacterial strains ( $n$ number of representatives)

\begin{tabular}{|c|c|c|c|}
\hline Phylum (n) & Class $(n)$ & OTUs $(n)$ & Genera $(n)$ \\
\hline \multirow[t]{2}{*}{ Actinobacteria (2) } & & 2 & Cellulomonas (1) \\
\hline & & & Diaminobutyricibacter (1) \\
\hline \multirow[t]{2}{*}{ Firmicutes (2) } & & 2 & Bacillus (1) \\
\hline & & & Paenibacillus (1) \\
\hline \multirow[t]{4}{*}{ Bacteroidetes (12) } & & 12 & Mucilaginibacter (5) \\
\hline & & & Pedobacter (4) \\
\hline & & & Chryseobacterium (2) \\
\hline & & & Flavobacterium (1) \\
\hline \multirow[t]{11}{*}{ Proteobacteria (52) } & Alphaproteobacteria (2) & 2 & Rhizobium (1) \\
\hline & & & Mesorhizobium (1) \\
\hline & Betaproteobacteria (31) & 14 & Paraburkholderia (10) \\
\hline & & & Caballeronia $(9)$ \\
\hline & & & Collimonas (9) \\
\hline & & & Variovorax (2) \\
\hline & & & Burkholderia (1) \\
\hline & Gammaproteobacteria (19) & 10 & Luteibacter (7) \\
\hline & & & Pseudomonas (6) \\
\hline & & & Dyella (4) \\
\hline & & & Rhodanobacter (2) \\
\hline
\end{tabular}




\section{Enzyme activities}

\section{Enzyme activities for the utilization of organic polymers}

A total of 68 strains were tested for enzyme activities required for the utilization of organic polymers using the plate assay method. All tested 68 strains could grow (which does not mean activity) on agar plates supplemented with $\mathrm{CMC}$ at 5 ${ }^{\circ} \mathrm{C}$ and $20^{\circ} \mathrm{C}$. The supplementation of the medium with xylan, PGA, or micCell, however, resulted partly in growth inhibition, being higher at the lower incubation temperature. This was especially noted for xylan (growth inhibition of $44 \%$ and $16 \%$ of the strains at $5{ }^{\circ} \mathrm{C}$ and $20^{\circ} \mathrm{C}$, respectively) and PGA (inhibition of $26 \%$ and $6 \%$ at $5{ }^{\circ} \mathrm{C}$ and $20^{\circ} \mathrm{C}$, respectively).

However, a considerable number of strains produced the enzymes required for substrate degradation (Table S1). A slightly higher amount of strains tested positive for enzyme activities at $5{ }^{\circ} \mathrm{C}(68 \%, 46$ strains $)$ than at $20{ }^{\circ} \mathrm{C}(63 \%, 43$ strains), which demonstrated the adaptation of the strains to low temperature conditions (Table 2). Among the positively tested strains (Table 3), more than one-third showed CMCase activity $\left(35 \%\right.$ at $5{ }^{\circ} \mathrm{C}, 40 \%$ at $20{ }^{\circ} \mathrm{C}$ ). Avicelase activity (cellulose-1,4- $\beta$-cellobiosidase; micCell hydrolysis) was detected to a significantly higher extent at $5{ }^{\circ} \mathrm{C}(39 \%$ of the positive

Table 2 Effect of temperature on the bacterial production of enzymes for the degradation of organic polymers and the utilization of lignins and organic pollutants as sole carbon source $(100 \%=68)$

\begin{tabular}{|c|c|c|c|}
\hline \multirow[t]{2}{*}{ Activity } & \multicolumn{2}{|c|}{$5^{\circ} \mathrm{C}$} & $20^{\circ} \mathrm{C}$ \\
\hline & $n$ & $\%$ & $\%$ \\
\hline
\end{tabular}

\begin{tabular}{lrrrr}
\hline Enzyme activities & & & & \\
CMCase & 16 & 23.5 & 17 & 25.0 \\
Avicelase & 18 & 26.5 & 8 & 11.8 \\
Xylanase & 7 & 10.3 & 10 & 14.7 \\
Pectate lyase & 5 & 7.4 & 8 & 11.8 \\
Total positive & 46 & 67.6 & 43 & 63.2 \\
C1,2D only & 50 & 73.5 & 45 & 66.2 \\
C2,3D only & 0 & 0.0 & 0 & 0.0 \\
C1,2D + C2,3D & 12 & 17.6 & 19 & 27.9 \\
Lignins as sole C source & & & & \\
LSS & 14 & 20.6 & 34 & 50.0 \\
Lignin alkali & 2 & 2.9 & 5 & 7.4 \\
Total positive & 16 & 23.5 & 39 & 57.4 \\
Organic pollutants as sole C source & & & \\
n-Hexadecane & 5 & 7.4 & 7 & 10.3 \\
Diesel oil & 3 & 4.4 & 17 & 25.0 \\
Phenol & 1 & 1.5 & 1 & 1.5 \\
Glyphosate & 1 & 1.5 & 14 & 20.6 \\
Total positive & 10 & 14.7 & 39 & 57.4 \\
\hline
\end{tabular}

strains) than at $20^{\circ} \mathrm{C}(19 \%)$. Generally, strains tended to utilize either $\mathrm{CMC}$ or micCell, only few strains were able to degrade both cellulose compounds. CMCase activity was found in all Gram-positive representatives and frequently present in members of Bacteroidetes, and Beta- and Gammaproteobacteria. About one-third (6 strains) of the 19 Gammaproteobacteria members displayed CMCase activity only at $5{ }^{\circ} \mathrm{C}$ but not at $20^{\circ} \mathrm{C}$. In contrast, micCell degradation restricted to $5{ }^{\circ} \mathrm{C}$ was detected at a frequency of ca. $20 \%$ in Beta- and Gammaproteobacteria members. The ability to degrade $P G A$ was restricted to representatives of Gammaproteobacteria (genera Pseudomonas and Luteibacter) and was more often detected at $20{ }^{\circ} \mathrm{C}(19 \%$ of the positive strains) than at $5{ }^{\circ} \mathrm{C}(11 \%)$ (Table S1).

Several strains produced more than one of the tested enzyme activities. One strain (Luteibacter rhizovicinus AR2065 , Gammaproteobacteria) displayed at $5{ }^{\circ} \mathrm{C}$ all four enzyme activities tested, while none of the strains showed this ability at $20{ }^{\circ} \mathrm{C}$. Three strains (all of them members of Bacteroidetes: genera Chryseobacterium, Mucilaginibacter, Pedobacter) utilized all enzyme substrates except PGA at $20^{\circ} \mathrm{C}$. Two strains (Pseudomonas, Pedobacter) degraded three enzyme substrates at $5{ }^{\circ} \mathrm{C}$. A higher amount of strains produced two enzyme activities $\left(10\right.$ and 8 strains at $5{ }^{\circ} \mathrm{C}$ and $20{ }^{\circ} \mathrm{C}$, respectively). The majority, however, expressed one enzyme activity (16 and 18 strains at $5^{\circ} \mathrm{C}$ and $20^{\circ} \mathrm{C}$, respectively).

\section{Catechol dioxygenases}

Catechol dioxygenase activities are involved in the second step of phenol degradation and catalyze the ring cleavage of catechol. Constitutively expressed catechol dioxygenase production was evaluated by using standardized cell suspensions, which were prepared by adjusting the $A_{600}$ values of all cell suspensions to 1.5; this way, it was possible to compare the activities of the tested strains. None of the 68 strains produced only $\mathrm{C} 2,3 \mathrm{D}$, while more than two-thirds showed only $\mathrm{C} 1,2 \mathrm{D}$ both at $5{ }^{\circ} \mathrm{C}(74 \%)$ and $20{ }^{\circ} \mathrm{C}(66 \%)$ (Table 2). Among the $\mathrm{C} 1,2 \mathrm{D}$-positive strains, a considerable part was able to produce additionally $\mathrm{C} 2,3 \mathrm{D}$ at $5{ }^{\circ} \mathrm{C}(24 \%)$ and $20{ }^{\circ} \mathrm{C}(42 \%$, among them 5 of the 6 representatives of OTU2, belonging to Collimonas pratensis, Betaproteobacteria). All strainsexcept one - that produced both $\mathrm{C} 1,2 \mathrm{D}$ and $\mathrm{C} 2,3 \mathrm{D}$ at $5{ }^{\circ} \mathrm{C}$ were able to produce both enzymes also at $20^{\circ} \mathrm{C}$, while the reverse was not noted (i.e., production at $20^{\circ} \mathrm{C}$ was not combined with production at $5^{\circ} \mathrm{C}$ ). $\mathrm{C} 1,2 \mathrm{D}$ was present in almost all phylogenetic representatives; the highest frequency of C2,3D was found in Bacteroidetes representatives (Table S1). Generally, C1,2D was expressed to a higher extent than $\mathrm{C} 2,3 \mathrm{D}$. The majority of the strains (78\%) showed activities of $\mathrm{C} 1,2 \mathrm{D}$ in the range of $1-10 \mathrm{U} / \mathrm{A}_{600}$ at $5{ }^{\circ} \mathrm{C}$ and at 20 ${ }^{\circ} \mathrm{C}$, while $\mathrm{C} 2,3 \mathrm{D}$ activity was generally 10 -fold lower. 
Table 3 Effect of temperature on positively tested bacteria strains able to produce enzymes for the degradation of organic polymers and to utilize lignins and organic pollutants as sole carbon source $(100 \%=$ total positive)

\begin{tabular}{|c|c|c|c|c|}
\hline \multirow[t]{2}{*}{ Activity } & \multicolumn{2}{|c|}{$5^{\circ} \mathrm{C}$} & \multicolumn{2}{|c|}{$20^{\circ} \mathrm{C}$} \\
\hline & $n$ & $\%$ & $n$ & $\%$ \\
\hline \multicolumn{5}{|c|}{ Enzyme activities } \\
\hline CMCase & 16 & 34.8 & 17 & 39.5 \\
\hline Avicelase & 18 & 39.1 & 8 & 18.6 \\
\hline Xylanase & 7 & 15.2 & 10 & 23.3 \\
\hline Pectate lyase & 5 & 10.9 & 8 & 18.6 \\
\hline Total positive & 46 & 100.0 & 43 & 100.0 \\
\hline \multicolumn{5}{|c|}{ Lignins as sole $\mathrm{C}$ source } \\
\hline LSS & 14 & 87.5 & 34 & 87.2 \\
\hline Lignin alkali & 2 & 12.5 & 5 & 12.8 \\
\hline Total positive & 16 & 100 & 39 & 100 \\
\hline \multicolumn{5}{|c|}{ Organic pollutants as sole $\mathrm{C}$ source } \\
\hline n-Hexadecane & 5 & 50.0 & 7 & 17.9 \\
\hline Diesel oil & 3 & 30.0 & 17 & 43.6 \\
\hline Phenol & 1 & 10.0 & 1 & 2.6 \\
\hline Glyphosate & 1 & 10.0 & 14 & 35.9 \\
\hline Total positive & 10 & 100.0 & 39 & 100.0 \\
\hline
\end{tabular}

\section{Utilization of lignin as sole carbon source}

The 68 strains were tested for their ability to utilize LSS or lignin alkali as sole carbon source on agar plates. A significantly higher fraction was able to utilize these lignin compounds at $20{ }^{\circ} \mathrm{C}(39$ strains, $57 \%)$ than at $5{ }^{\circ} \mathrm{C}(16$ strains, 24\%) (Table 2, Table S1). However, among these positive strains (Table 3), the relative fractions utilizing the two lignin compounds ( $87 \%$ utilized LSS, $13 \%$ lignin alkali) were almost identical at $5{ }^{\circ} \mathrm{C}$ and $20^{\circ} \mathrm{C}$. Independent of the cultivation temperature, LSS was preferred by a significantly higher amount of strains compared with lignin alkali. Especially representatives of the order Burkholderiales (Betaproteobacteria) were found among LSS utilizers. In contrast, most of lignin alkali utilizers belonged to the genus Pseudomonas (Gammaproteobacteria). Only 1 strain (Pseudomonas AR2070) was able to grow with both compounds as sole carbon source at both temperatures (Table S1).

The LSS degradation potential of two strains, Paraburkholderia aromaticivorans AR20-38 (Poyntner et al. 2020) and Caballeronia udeis AR20-07 (both representatives of Betaproteobacteria, but belonging to different OTUs), was further tested in liquid culture. Both strains showed very similar growth patterns: good growth with LSS $(2 \mathrm{~g} / \mathrm{L})$ was visible after $24 \mathrm{~h}$ at temperatures ranging from 5 to $30{ }^{\circ} \mathrm{C}$; growth at $0{ }^{\circ} \mathrm{C}$ was $48 \mathrm{~h}$ delayed. The highest amount of biomass was produced at $15-30{ }^{\circ} \mathrm{C}$; strain AR20-38 showed significantly better growth in the low temperature $\left(0-10^{\circ} \mathrm{C}\right)$ range than strain AR20-07 (Fig. 2).

Both strains utilized LSS amounts up to $15 \mathrm{~g} / \mathrm{L}$ as sole carbon source. The higher the LSS concentration, the higher was the amount of biomass (i.e., biomass production was a linear function of LSS concentration); for example, both strains produced in the presence of $10 \mathrm{~g} / \mathrm{L}$ LLS a ca. threefold higher biomass than in the presence of $2 \mathrm{~g} / \mathrm{L}$ LLS. Independent of the LSS content, the stationary growth phase was reached after 48-72 $\mathrm{h}$ (data not shown).

\section{Utilization of organic pollutants as sole carbon source}

The screening for utilization of one the organic pollutants nhexadecane, diesel oil, phenol, and glyphosate as sole carbon sources on agar plates at $5{ }^{\circ} \mathrm{C}$ and $20^{\circ} \mathrm{C}$ demonstrated that only a low fraction of the 68 tested strains was able to utilize one of the tested compounds at $5{ }^{\circ} \mathrm{C}(10$ strains, $15 \%)$ or $20^{\circ} \mathrm{C}$ (39 strains, 57\%) (Table 2, Table S1).

Of the positive strains, substrate utilization was completely different at the two cultivation temperatures (Table 3). At 20 ${ }^{\circ} \mathrm{C}$, the majority utilized diesel oil (44\%) or glyphosate (36\%) as the sole carbon source; at $5{ }^{\circ} \mathrm{C}$, hexadecane (50\%) or diesel oil (30\%) was preferred. One strain (Paraburkholderia aromaticivorans AR20-38) utilized phenol very well for growth at $5{ }^{\circ} \mathrm{C}$ and $20{ }^{\circ} \mathrm{C}$. Glyphosate was utilized by $21 \%$ at $20^{\circ} \mathrm{C}$, however, only by 1 strain (Pedobacter cryoconitis AR20-108) at $5{ }^{\circ} \mathrm{C}$. C16 and diesel oil were preferentially utilized by members of Bacteroidetes and Betaproteobacteria at $20^{\circ} \mathrm{C}$, while glyphosate was mainly utilized by members of Bacteroidetes (Table S1).

None of the positive strains could utilize all four tested compounds at any of the test temperatures. The utilization of three out of the four compounds at $5^{\circ} \mathrm{C}$ was noted by 1 strain (Pedobacter cryoconitis AR20-108), while 5 strains had this

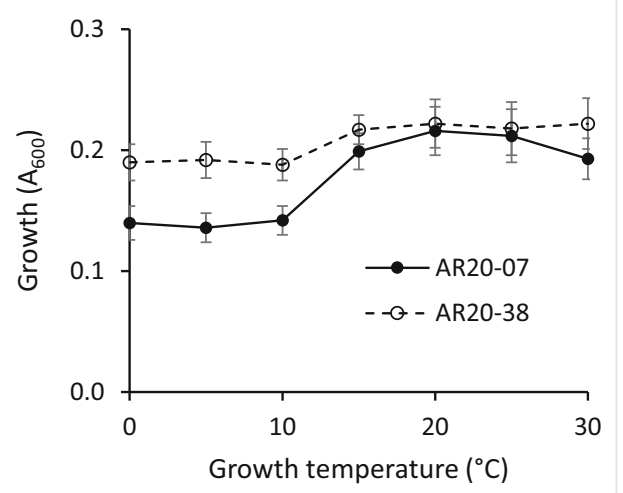

Fig. 2 Effect of temperature on the utilization of LSS as sole carbon source by the two bacterial strains Paraburkholderia aromaticivorans AR20-38 and Caballeronia udeis AR20-07 (mean values \pm SD of three replicates) 
ability at $20^{\circ} \mathrm{C}$. The majority utilized one of the compounds at $5{ }^{\circ} \mathrm{C}$ (5 strains) and $20^{\circ} \mathrm{C}(16$ strains $)$, respectively.

Strain AR20-38 (Paraburkholderia aromaticivorans; for characterization and identification of the strain see Poyntner et al. 2020) showed good growth both at $5{ }^{\circ} \mathrm{C}$ and $20^{\circ} \mathrm{C}$ on agar plates containing $2.5 \mathrm{mmol} / \mathrm{L}$ phenol as the sole carbon source. Its phenol degradation potential was further tested in liquid culture. The evaluation of the effects of temperature (over the growth temperature range $0-30{ }^{\circ} \mathrm{C}$ ) and phenol content demonstrated an increase in the lag phase with decreasing temperatures and increasing amounts of phenol (Fig. 3). An initial phenol content of $2.5 \mathrm{mmol} / \mathrm{L}$ resulted in complete phenol degradation after 1 day at $25-30^{\circ} \mathrm{C}$, after $2-3$ days at 10 $20^{\circ} \mathrm{C}$, and after 8 and 14 days at $5{ }^{\circ} \mathrm{C}$ and $0{ }^{\circ} \mathrm{C}$, respectively. A phenol content of $5 \mathrm{mmol} / \mathrm{L}$ resulted in significantly reduced growth at $0-5{ }^{\circ} \mathrm{C}$; complete phenol degradation occurred after 2 days at $25^{\circ} \mathrm{C}$, after 3 days at $15-20$, and 30 ${ }^{\circ} \mathrm{C}$ and after 5 days at $10^{\circ} \mathrm{C}$. Biodegradation at lower temperatures was very low $\left(19 \%\right.$ at $5{ }^{\circ} \mathrm{C}, 7 \%$ at $\left.0{ }^{\circ} \mathrm{C}\right)$. A similar pattern was observed at an initial phenol content of 7.5 $\mathrm{mmol} / \mathrm{L}$. The best growth was obtained at $25^{\circ} \mathrm{C}$, followed by $15-20{ }^{\circ} \mathrm{C}$. Growth at $30^{\circ} \mathrm{C}$ was already $50 \%$ lower. Full biodegradation occurred after 4 days at $25-30{ }^{\circ} \mathrm{C}$ and after $7-$ 8 days at $15-20^{\circ} \mathrm{C}$. Growth and biodegradation were almost negligible at $0-5{ }^{\circ} \mathrm{C}(8-12 \%) .10 \mathrm{mmol} / \mathrm{L}$ phenol was not degraded at any of the temperatures.

\section{Discussion}

The soil bacterial diversity at the Alpine coniferous forest site $\mathrm{R}$ has been reported (França et al. 2016). The majority of the 68 studied strains belonged to the phylum Proteobacteria, with a predominance of Beta- and Gammaproteobacteria, and a very low proportion of Alphaproteobacteria and Grampositive representatives. The low presence of Gram-positive bacteria in Alpine soils has already been observed and can be attributed to their lower competitivity compared with Gramnegative bacteria, caused by, e.g., lower tolerance to freezethaw cycles and the promoting effect of plant roots towards Gammaproteobacteria (Margesin et al. 2009; França et al. 2016). However, a high abundance of Gram-positive representatives (mycobacteria) has been found in acidic boreal coniferous forest soils (Iivanainen et al. 1997).
Fig. 3 Effect of temperature and phenol concentration (top panels: $2.5 \mathrm{mmol} / \mathrm{L}$; middle panels: 5 mmol/L; bottom panels: 7.5 $\mathrm{mmol} / \mathrm{L}$ ) on growth (left panels) and phenol degradation (right panels) by strain Paraburkholderia aromaticivorans AR20-38 (mean values of three replicates, SDs were $\leq 10 \%$ )
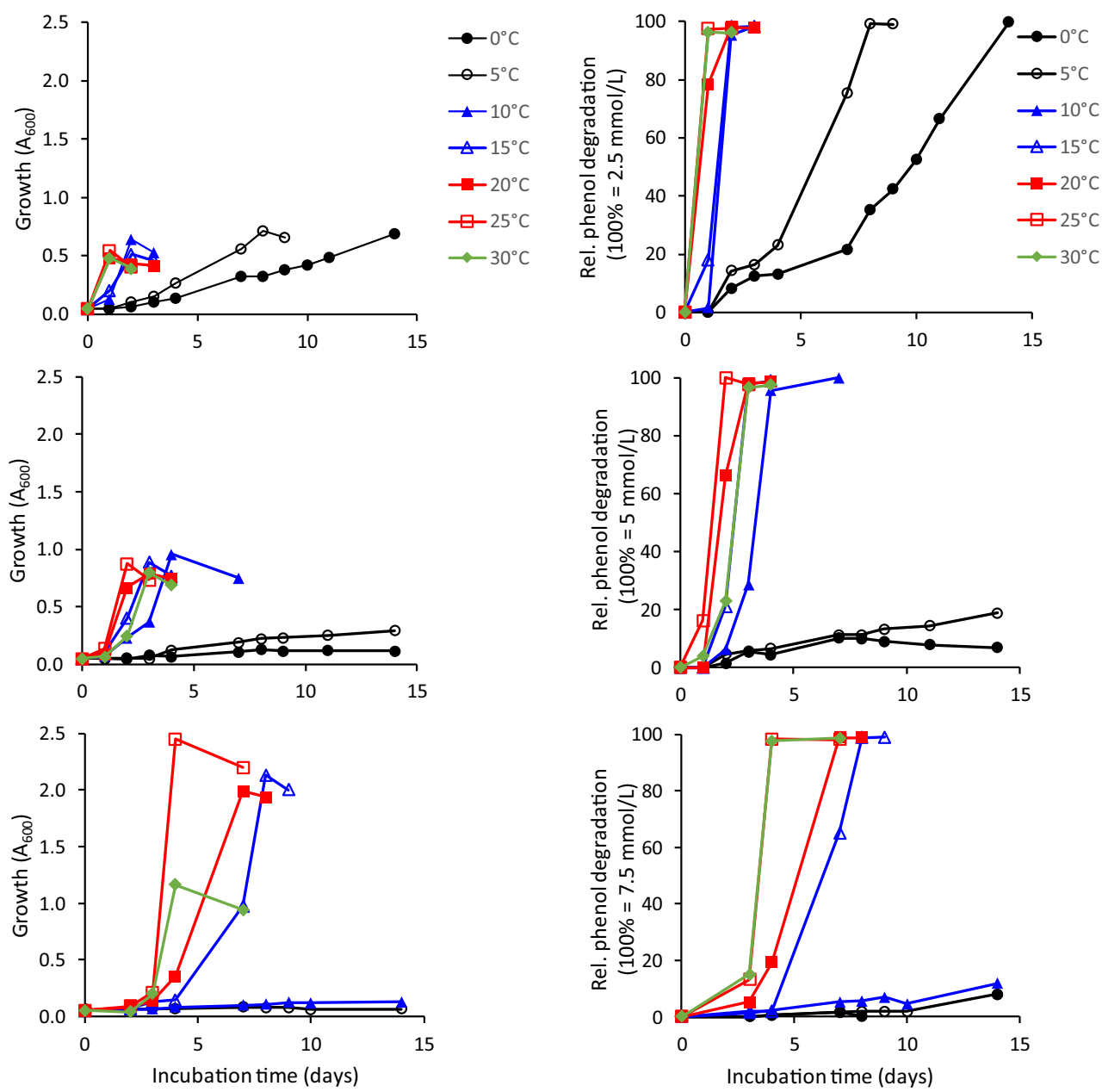
In adaptation to the site-specific climate conditions, all strains, except one, were able to grow well over a broad temperature range from 5 to $25^{\circ} \mathrm{C}$. Representatives of the genera Caballeronia and Collimonas (Betaproteobacteria) were especially qualified for growth below $20^{\circ} \mathrm{C}$. These genera have already been described in cold soils (Männistö and Häggblom 2006; Zumsteg et al. 2013).

The majority of the organic matter in forest soils originates from plants. The screening for enzymes involved in the utilization of organic polymers present in litter demonstrated the widely distributed ability of the strains to degrade celluloses, xylan, and PGA both at low $\left(0{ }^{\circ} \mathrm{C}\right)$ and moderate $\left(20{ }^{\circ} \mathrm{C}\right)$ temperatures. Enzyme activities are required for the efficient litter decomposition and nutrient turnover in forest soils.

The main and most abundant cell wall polymer is cellulose and can be degraded by bacteria and fungi (Islam and Roy 2019). The cellulase complex consists of three major groups of cellulases (Yang et al. 2019). The high amount of strains in this study able to hydrolyze celluloses indicates that cellulases represent the main enzyme activities of the strains and demonstrates the bacterial role in litter decomposition. The presence of cellulose degraders at site $\mathrm{R}$ has been earlier observed (Margesin et al. 2016; Siles and Margesin 2017); however, in these studies, it was not possible to evaluate their response to temperature with regard to enzyme production. The almost comparable amount of (both Gram negative and Gram positive) CMC-hydrolyzing bacteria at low and moderate temperatures $\left(5^{\circ} \mathrm{C}\right.$ and $\left.20^{\circ} \mathrm{C}\right)$ shown in this study indicates the wide distribution of this activity among soil bacteria, regardless of taxonomic affiliation or temperature. CMC is a water-soluble substrate that can be easily degraded by microorganisms. In contrast, the significantly higher proportion of strains able to hydrolyze the recalcitrant substrate micCell (avicelase) at $5^{\circ} \mathrm{C}$ than at $20^{\circ} \mathrm{C}$ points to the bacterial adaptation for the utilization of recalcitrant compounds at low temperatures, i.e., conditions prevailing at the site. As a consequence of the higher recalcitrance of coniferous litter, SOM at this site contains a high amount of aromatic compounds (Siles et al. 2017). Interestingly, strains tended to utilize either $\mathrm{CMC}$ or micCell, which points to the specialization of degraders for easily decomposable or recalcitrant compounds. Ladeira et al. (2015) hypothesized complex mechanisms of interaction within different types of cellulases. Generally, many cellulase producers at $5{ }^{\circ} \mathrm{C}$ belonged to Gammaproteobacteria. The production of polysaccharide-degrading enzymes by this class in cold environments has been reported (Jain and Krishnan 2017).

Xylan is a major polysaccharide in plant cell walls, and thus a quantitatively important carbon polymer in nature, found in hard wood, soft wood, and grasses. Xylan degradation is mainly conducted by microbial xylanases in nature; xylanases in cold Alpine soils have been described to be very diverse (Wang et al. 2010). Beside of cellulase, xylanase is the most important enzyme of primary litter degradation (Schinner et al. 1996). In our study, xylanase production was detected both at low and moderate temperature conditions, however, only by representatives of Bacteroidetes, and Beta- and Gammaproteobacteria. Xylanolytic representatives of these groups have also been described in Alpine tundra soil (Wang et al. 2010).

Pectic substances are ubiquitous in the plant kingdom. Microbial enzymes play a significant role for the decomposition and recycling of plant organic matter. The depolymerizing enzymes include polygalacturonidases and lyases, which cleave the glycosidic bonds by $\beta$-elimination (Margesin et al. 2005; Atanasova et al. 2018). The fraction of bacterial strains able to degrade PGA was lower than the fraction that utilized celluloses or xylan. This can be explained by the fact that pectic substances are not dominant in coniferous litter. The growth-inhibiting effects of xylan and PGA observed on agar plates in our study have already been reported and explained with the inhibitory or toxic effect of compounds released from these substrates during biodegradation (Rosenblatt et al. 2017; Brandon et al. 2018).

Another important biopolymer of plant cell walls is lignin. Lignin is the second most abundant organic substance in the world (Ganewatta et al. 2019). Due to its complex structure, comprising a matrix of phenolic and aliphatic substances, lignin is one of the most recalcitrant biopolymers (Bugg et al. 2011; Ganewatta et al. 2019). After plant death, lignin undergoes natural biodegradation by soil microorganisms, which results in the formation of SOM. In our study, a significantly higher number of strains utilized LSS as sole carbon source compared with lignin alkali. This can be explained by the water solubility and thus "easy" biodegradability of LSS (Silva et al. 2010), whereas lignin alkali is water insoluble and thus has a lower bioavailability (Chandra et al. 2008). Interestingly, all strains able to utilize lignin alkali belonged to the genus Pseudomonas (Gammaproteobacteria), while Burkholderiales dominated among LSS utilizers. Both groups have been described as efficient ligninolytic soil bacteria (Liu et al. 2019). There are a number of studies of bacteria able to degrade lignin, although earlier studies have focused on lignin breakdown by fungi (Bugg et al. 2011; Ganewatta et al. 2019).

Since lignin contains a high amount of aromatic and aliphatic compounds and a possible link between the degradation of aromatic compounds and lignin by soil bacteria has been observed (Bugg et al. 2011), we tested the ability of the bacterial strains to utilize organic pollutants as sole carbon source, to explore their potential for low temperature bioremediation. C16 and diesel oil were utilized especially by Bacteroidetes and Betaproteobacteria, both at low and moderate temperatures. Bacteroidetes were also mainly involved in the utilization of the pesticide glyphosate. Due to the ubiquity of hydrocarbons, bacteria capable of their utilization are present in every soil type, not only in contaminated ones 
(Welander 2005; Czarny et al. 2017). For example, bacteria capable of degrading a number of polyaromatic hydrocarbons were detected in non-contaminated mountain forest soil (Song et al. 2016). However, a higher amount of genes associated with biodegradation processes was found in contaminated soils (Czarny et al. 2017).

Phenolic compounds are highly toxic to microorganisms and can often cause the breakdown of wastewater treatment plants by inhibition of microbial growth even at low concentrations $(<2 \mathrm{mmol} / \mathrm{L})$. Strain Paraburkholderia aromaticivorans AR20-38 utilized phenol over its whole growth temperature range $\left(0-30{ }^{\circ} \mathrm{C}\right)$ and up to an amount of $7.5 \mathrm{mmol} / \mathrm{L}$; its draft genome sequence has been described recently (Poyntner et al. 2020). The strain used the ortho type $(\mathrm{C} 1,2 \mathrm{D})$ of ring cleavage both at $5{ }^{\circ} \mathrm{C}$ and $20^{\circ} \mathrm{C}$. Ortho ring cleavage of catechol has also been observed with a representative of Paraburkholderia phytofirmans (Donos et al. 2017). The biodegradation potential of members of the genus Paraburkholderia for aromatic compounds has been reported (Li et al. 2017; Lee and Jeon 2018; Yuan et al. 2018). Community analyses showed that Paraburkholderia species degrade rarely $n$-hexadecane (Lee et al. 2019). The versatile metabolic capabilities of a representative of Paraburkholderia aromaticivorans (Lee et al. 2019) can also be assigned to strain AR20-38, since the strain utilizes lignin (this study) and a number of aromatic and polyaromatic hydrocarbons (catechol, phenol, naphthalene, phenanthrene) as sole carbon source (data not shown).

Catechol dioxygenase activities catalyze the ring cleavage of catechol. In our study, constitutively expressed catechol dioxygenase production was detected at low and moderate temperatures among a considerable part of the studied strains. Our data also indicated the clear preference of the ortho type $(\mathrm{C} 1,2 \mathrm{D})$ of ring cleavage for the oxidation of catechol. The predominance of the ortho-pathway has already been noted (Margesin et al. 2003, 2013). The additional presence of the meta type $(\mathrm{C} 2,3 \mathrm{D})$ of ring cleavage in some strains was especially noted at $5{ }^{\circ} \mathrm{C}$. The constitutive expression of enzymes involved in the degradation of aromatic compounds may present an advantage for the immediate microbial response to forest litter.

In conclusion, the results reported in this study clearly demonstrate the degradation potential of culturable soil bacteria from Alpine coniferous forest site for organic polymers and pollutants. Representatives of Bacteroidetes were especially versatile. Thus, we proved the activity of genes that were found with the functional, however DNA-based, characterization of the soil microbial community (Siles and Margesin 2017). These results are useful to better understand the effect of changing temperatures on soil microorganisms involved in litter degradation and nutrient turnover. With an increase of soil temperatures in Alpine regions, as predicted due to global climate change (Gobiet et al. 2014), soil bacteria at the studied
Alpine coniferous forest site could contribute to increased rates of SOM and litter degradation, which in turn could contribute to a positive feedback in climate warming. In addition, the demonstrated low temperature degradation potential and production of a range of enzymes could be useful for biotechnological application (Collins and Margesin 2019).

Funding Open access funding provided by University of Innsbruck and Medical University of Innsbruck.

\section{Compliance with ethical standards}

Conflict of interest The authors declare that they have no conflict of interest.

Open Access This article is licensed under a Creative Commons Attribution 4.0 International License, which permits use, sharing, adaptation, distribution and reproduction in any medium or format, as long as you give appropriate credit to the original author(s) and the source, provide a link to the Creative Commons licence, and indicate if changes were made. The images or other third party material in this article are included in the article's Creative Commons licence, unless indicated otherwise in a credit line to the material. If material is not included in the article's Creative Commons licence and your intended use is not permitted by statutory regulation or exceeds the permitted use, you will need to obtain permission directly from the copyright holder. To view a copy of this licence, visit http://creativecommons.org/licenses/by/4.0/.

\section{References}

Allsop PJ, Chisti Y, Moo-Young M, Sullivan GR (1993) Dynamics of phenol degradation by Pseudomonas putida. Biotechnol Bioeng 41: 572-580

Atanasova L, Dubey M, Grujić M, Gudmundsson M, Lorenz C, Sandgren M, Kubicek CP, Jemsem DF, Karlsson M (2018) Evolution and functional characterization of pectate lyase PEL12, a member of a highly expanded Clonostachys rosea polysaccharide lyase 1 family. BMC Microbiol 18:178

Baldrian P (2017) Forest microbiome: diversity, complexity and dynamics. FEMS Microbiol Rev 41:109-130. https://doi.org/10.1093/ femsre/fuw040

Brandon A, Scheller HV, Loque D (2018) Mutant xylan biosynthetic enzymes capable of dominant suppression of xylan biosynthesis. US Patent Application

Bugg TDH, Ahmad M, Hardiman EM, Singh R (2011) The emerging role for bacteria in lignin degradation and bio-product formation. Curr Opin Biotechnol 22:394-400

Chandra R, Singh S, Reddy MMK, Patel DK, Purohit HJ, Kapley A (2008) Isolation and characterization of bacterial strains Paenibacillus sp. and Bacillus sp. for kraft lignin decolorization from pulp paper mill waste. J Gen Appl Microbiol 54:399-407

Collins T, Margesin R (2019) Psychrophilic lifestyles: mechanisms of adaptation and biotechnological tools. Appl Microbiol Biotechnol 103:2857-2871. https://doi.org/10.1007/s00253-019-09659-C5

Czarny J, Staninska-Pieta J, Powierska-Czarny J, Nowak J, Wolko L, Piotrowska-Cyplik A (2017) Metagenomic analysis of soil bacterial community and level of genes responsible for biodegradation of aromatic hydrocarbons. Pol J Microbiol 66:345-352

Donos R, Leiva-Novoa P, Zúñiga A, Timmermann T, RecabarrenGajardo G, Gonzáles (2017) Biochemical and genetic bases of 
indole-3-acetic acid (auxin phytohormone) degradation by the plantgrowth-promoting rhizobacterium Paraburkholderia phytofirmans PsJN. Appl Environ Microbiol 83:1

França L, Sannino C, Turchetti B, Buzzini P, Margesin R (2016) Seasonal and altitudinal changes of culturable bacterial and yeast diversity in Alpine forest soils. Extremophiles 20:855-873. https://doi.org/10. 1007/s00792-016-0874-2

Ganewatta MS, Lokupitiya HN, Tang C (2019) Lignin biopolymers in the age of controlled polymerization. Poylmers 11:1176. https://doi. org/10.3390/polym1 1071176

Gebbie L, Dam TT, Ainscough R, Palfreyman R, Cao L, Harrison M, O'Hara I, Speight R (2020) A snapshot of microbial diversity and function in an undisturbed sugarcane bagasse pile. BMC Biotechnol 20:12

Gobiet A, Kotlarski S, Beniston M, Heinrich G, Rajczak J, Stoffel M (2014) 21st century climate change in the European Alps-A review. Sci Total Environ 493:138-1151

Iivanainen EK, Martikainen PJ, Raisanen ML, Katila ML (1997) Mycobacteria in boreal forest soils. FEMS Microbiol Ecol 23: 325-332

Islam F, Roy N (2019) Isolation and characterization of cellulaseproducing bacteria from sugar industry waste. Am J Biosci 7:16-24

Jain A, Krishnan KP (2017) A glimpse of the diversity of complex polysaccharide-degrading culturable bacteria from Kongsfjorden, Arctic Ocean. Arch Microbiol 67:203-214

Kim O-S, Cho Y-J, Lee K, Yoon S-H, Kim M, Na H, Park S-C, Jeon YS, Lee J-H, Yi H, Won S, Chun J (2012) Introducing EzTaxon-e: a prokaryotic $16 \mathrm{~S}$ rRNA gene sequence database with phylotypes that represent uncultured species. Int J Syst Evol Microbiol 62:716-721

Kimura M (1980) A simple method for estimating evolutionary rate of base substitutions through comparative studies of nucleotide sequences. J Mol Evol 16:111-120

Kumar S, Stecher G, Li M, Knyaz C, Tamura K (2018) 1MEGA X: Molecular evolutionary genetics analysis across computing platforms. Mol Biol Evol 35:1547-1549. https://doi.org/10.1093/ molbev/msy096

Ladeira SA, Cruz E, Delatorre AB, Barbosa JB, Martins MLL (2015) Cellulase production by thermophilic Bacillus sp. SMIA-2 and its detergent compatibility. Electron J Biotechnol 18:110-115

Lane D (1991) 16S/23S rRNA sequencing. In: Stackebrandt E, Goodfellow M (eds) Nucleic acid techniques in bacterial systematics. Wiley, Chichester, pp 115-175

Lee Y, Jeon CO (2018) Paraburkholderia aromaticivorans sp. nov., an aromatic hydrocarbon-degrading bacterium, isolated from gasolinecontaminated soil. Int J Syst Evol Microbiol 68:1251-1257

Lee Y, Lee Y, Jeon CO (2019) Biodegradation of naphthalene, BTEX, and aliphatic hydrocarbons by Paraburkholderia aromaticivorans BN5 isolated from petroleum-contaminated soil. Sci Rep 9:860

Li J, Wang G, Allison SD, Mayes MA, Luo Y (2014) Soil carbon sensitivity to temperature and carbon use efficiency compared across microbial-ecosystem models of varying complexity. Biogeochemistry 119:67-84. https://doi.org/10.1007/s10533-0139948-8

Li D, Feng L, Liu K, Cheng Y, Hou N, Li C (2016) Optimization of coldactive CMCase production by psychrotrophic Sphingomonas sp. FLX-7 from the cold region of China. Cellulose 23:1335-1347. https://doi.org/10.1007/s10570-016-0859-4

Li JB, Zhang DY, Song MK, Jiang LF, Wang YJ, Luo CL, Zhang G (2017) Novel bacteria capable of degrading phenanthrene in activated sludge reveled by stable-isotope probing coupled with highthroughput sequencing. Biodegradation 28:423-436

Liu ZH, Le RK, Kosa M, Yang B, Yuan J, Ragauskas AJ (2019) Identifying and creating pathways to improve biological lignin valorisation. Renew Sust Energ Rev 105:349-362
Männistö MK, Häggblom MM (2006) Characterization of psychrotolerant heterotrophic bacteria from Finnish Lapland. Syst Appl Microbiol 29:229-243

Margesin R, Schinner F (1997) Bioremediation of diesel-oil contaminated alpine soils at low temperatures. Appl Microbiol Biotechnol 47: $462-468$

Margesin R, Gander S, Zacke G, Gounot AM, Schinner F (2003) Hydrocarbon degradation and enzyme activities of cold-adapted bacteria and yeasts. Extremophiles 7:451-458

Margesin R, Fauster V, Fonteyne PA (2005) Characterization of coldactive pectate lyases from psychrophilic Mrakia frigida. Lett Appl Microbiol 40:453-459

Margesin R, Jud M, Tscherko D, Schinner F (2009) Microbial communities and activities in alpine and subalpine soils. FEMS Microbiol Ecol 67:208-218

Margesin R, Moertelmaier C, Mair J (2013) Low-temperature biodegradation of petroleum hydrocarbons (n-alkanes, phenol, anthracene, pyrene) by four actinobacterial strains. Int Biodeterior Biodegrad 84: 185-191

Margesin R, Minerbi S, Schinner F (2016) Litter decomposition at two forest sites in the Italian Alps: a field study. Arct Antarct Alp Res 48: 127-138. https://doi.org/10.1657/AAAR0015-012

Nakazawa T, Nakazawa A (1970) Pyrocatechase (Pseudomonas). Methods Enzymol 17A:518-522

Nei M, Kumar S (2000) Molecular evolution and phylogenetics. Oxford University Press, New York ISBN: 9780195135855

Nozaki M (1970) Metapyrocatechase (Pseudomonas). Methods Enzymol 17A:522-525

Poyntner C, Zhang D, Margesin R (2020) Draft genome sequence of the bacterium Paraburkholderia aromaticivorans AR20-38, a Gramnegative, cold-adapted degrader of aromatic compounds. Microbiol Resour Announc 9:e00463-e00420. https://doi.org/10. 1128/MRA.00463-20

Rosenblatt J, Reitzel RA, Vargas-Cruz N, Chaftari AM, Hachem R, Raad I (2017) Caprylic and polygalacturonic acid combinations for eradication of microbial organisms embedded in biofilm. Front Microbiol 8:1999

Sánchez-Hidalgo M, Pascual J, de la Cruz M, Martín J, Kath GS, Sigmung JM, Masurekar P, Vicente F, Genilloud O, Bills GF (2012) Prescreening bacterial colonies for bioactive molecules with Janus plates, a SBS standard double-faced microbial culturing system. Antonie Van Leeuwenhoek 102:361-374

Schinner F, Öhlinger R, Kandeler E, Margesin R (eds) (1996) Methods in soil biology. Springer Lab Manual, Berlin

Schloss PD, Westcott SL, Ryabin T, Hall JR, Hartmann M, Hollister EB, Lesniewski RA, Oakley BB, Parks DH, Robinson CJ, Sahl JW, Stres B, Thallinger GG, Van Horn DJ, Weber CF (2009) Introducing mothur: open-source, platform-independent, community-supported software for describing and comparing microbial communities. Appl Environ Microbiol 75:7537-7541

Siles JA, Margesin R (2017) Seasonal soil microbial responses are limited to changes in functionality at two Alpine forest sites differing in altitude and vegetation. Nat Sci Rep 7:2204. https://doi.org/10. 1038/s41598-017-02363-2

Siles JA, Cajthaml T, Minerbi S, Margesin R (2016) Effect of altitude and season on microbial activity, abundance and community structure in Alpine forest soils. FEMS Microbiol Ecol 92:fiw008. https://doi. org/10.1093/femsec/fiw008

Siles A, Cajthaml T, Filipová A, Minerbi S, Margesin R (2017) Altitudinal, seasonal and interannual shifts in microbial communities and chemical composition of soil organic matter in Alpine forest soils. Soil Biol Biochem 112:1-13. https://doi.org/10.1016/j.soilbio. 2017.04.014

Silva IS, Ragagnin de Menezes C, Franciscon E, Santos EC, Durrant LR (2010) Degradation of lignosulfonic and tannic acids by ligninolytic 
soil fungi cultivated under microaerobic conditions. Braz Arch Biol Technol 53:693-699

Song MK, Jiang LF, Zhang DY, Luo CL, Wang Y, Yu ZQ, Y in H, Zhang G (2016) Bacteria capable of degrading anthracene, phenanthrene, and fluoranthene as revealed by DNA based stable-isotope probing in a forest soil. J Hazard Mater 308:50-67

Wang G, Wang Y, Yang P, Luo H, Huang H, Shi P, Meng K, Yao B (2010) Molecular detection and diversity of xylanase genes in alpine tundra soil. Appl Microbiol Biotechnol 87:1383-1393

Welander U (2005) Microbial degradation of organic pollutants in soil in a cold climate. Soil Sediment Contam 14:281-291

Yang S, Yang B, Duan C, Fuller DA, Wang X, Chowdhury SP, Stavik J, Zhang H, Ni Y (2019) Applications of enzymatic technologies to the production of high-quality dissolving pulp: A review. Bioresour Technol 281:440-448
Yuan XY, Zhang XY, Cen XP, Kong DW, Liu XY, Shen SY (2018) Synergistic degradation of crude oil by indigenous bacterial consortium and exogenous fungus Scedosporium boydii. Bioresour Technol 264:190-197

Žif̌ćḱková L, Vetrovsky T, Lombard V, Henrissat B, Howe A, Baldrian P (2017) Feed in summer, rest in winter: microbial carbon utilization in forest topsoil. Microbiome 5:122

Zumsteg A, Schmutz S, Frey B (2013) Identification of biomass utilizing bacteria in a carbon-depleted glacier forefield soil by the use of $13 \mathrm{C}$ DNA stable isotope probing. Environ Microbiol Rep 5:424-437

Publisher's note Springer Nature remains neutral with regard to jurisdictional claims in published maps and institutional affiliations. 